УДК 597/599(571.63)

dx.doi.org/10.24866/7444-4911-7/8-11

\title{
Видовое многообразие и территориальное распределение наземныХ позвоночных Tetrapoda (Vertebrata, Chordata) Приморского края
}

\author{
Ю.Н. Глущенко ${ }^{1,2}$, э.И. Цунов ${ }^{1}$ \\ ${ }^{1}$ Дальневосточный фредеральный университет. Филиал в г. Уссурийске (Школа педагогики) \\ ${ }^{2}$ Тихоокеанский институт географии ДВО РАН (г. Владивосток)
}

\begin{abstract}
В публикации дано видовое многообразие и территориальное распределение наземных позвоночных Tetrapoda (Vertebrata, Gnathostomata), известных для территории Приморского края и прилежащей акватории Японского моря.
\end{abstract}

Ключевые слова: Приморский край, наземные позвоночные, Tetrapoda, видовое многообразие, распространение.

По видовому разнообразию наземных позвоночных (Tetrapoda) Приморский край занимает лидирующее положение среди субъектов Российской Федерации, в первую очередь за счёт значительного числа встречающихся здесь видов птиц, как наиболее представленного в видовом отношении класса тетрапод, составляющего 79,8\% от его списочного состава. Несмотря на достаточно хорошую фаунистическую изученность этой территории, в последнее время удаётся находить здесь всё новые виды: только за период с 2017 по 2020 гг. было выявлено семь новых видов птиц, а общий авифаунистический список Приморья к 2020 г. достиг 513 видов (Глущенко и др., 2020). Что касается локальной фрауны млекопитающих, то её видовой перечень в пять раз меньший, чем птиц (15,9\% от общего числа всех видов тетрапод региона), при этом недавно он был пополнен новым для России видом - водяным оленем Hydropotesinermis, первый случай достоверной встречи которого был зафиксирован в Хасанском районе (национальный парк «Земля леопарда») 1 апреля 2019 г. (Дарман и др., 2019).

Пресмыкающиеся и земноводные суммарно составляют лишь около 4,4\% регионального списочного состава рассматриваемого надкласса. Фауна и распространение земноводных по территории Приморья хорошо изучены (Кузьмин, Маслова, 2005; Maslova, 2016) и нахождение новых видов здесь маловероятно. Последние фраунистические пополнения списка пресмыкающихся осуществлены в 1978 г., когда в зал. Петра Великого был обнаружен большой морской крайтPseudolaticaudasemifasciata (Чугунов, 1980). Следует отметить, что в Российских водах Японского моря (скорее всего, в заливе Петра Великого) возможно хотя бы случайное нахождение ещё шести видов морских змей и одного вида морских черепах (Харин, 2008).

Ввиду мозаичности имеющихся в Приморье типов местообитаний, распределение различных животных, в том числе и тетрапод, по территории края носит неравномерный характер. Существуют различные способы районирования этой территории, наиболее простым из которых, безусловно, является административное деление, согласно которому здесь расположено 22 административных района и 12 городских округов. При таком подходе строго установлены пространственные границы выделов, однако использование этих фррагментов для того, чтобы представить территориальное распределение позвоночных животных не представляется удачным по целому ряду причин (территориальное неравенство этих выделов, их значительное количество, различная степень их изученности и т.д.). Зональное (биомное) районирование, предложенное В.Н. Бочарниковым с соавторами (2004), является 
более успешным, но наиболее приемлемым, на наш взгляд, является выделение секторов Приморского края на основе «бассейнового» подхода, в своё время разработанного и применённого для решения данной задачи сначала в отношении птиц (Глущенко и др. 2010), а затем и наземных представителей класса млекопитающих (Глущенко, Ромашина, 2015). Согласно этому приёму, территория Приморского края включает семь секторов. На их территории зарегистрировано от 339 до 588 видов наземных позвоночных из 643 видов, известных для Приморья в целом, и относящихся к четырём классам, 35 отрядам и 113 семействам (см. таблицу).

Многообразие наземных позвоночных (Tetrapoda) Приморского края

\begin{tabular}{|c|c|c|c|c|c|c|c|c|}
\hline \multirow[b]{2}{*}{ Количество } & \multicolumn{8}{|c|}{ Число особей по секторам } \\
\hline & 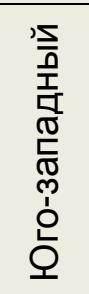 & 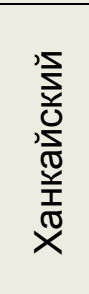 & 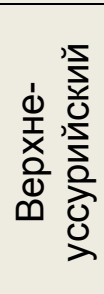 & 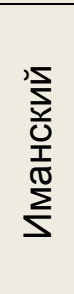 & 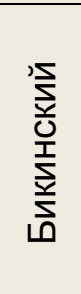 & 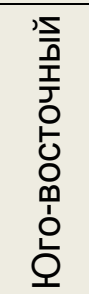 & 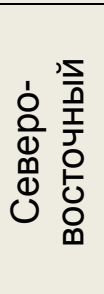 & 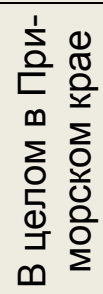 \\
\hline \multicolumn{9}{|c|}{ КЛАСС ЗЕМНОВОДНЫЕ - АМРНІВІА } \\
\hline Видов & 9 & 8 & 9 & 8 & 8 & 8 & 7 & 9 \\
\hline Семейств & 5 & 5 & 5 & 5 & 5 & 5 & 5 & 5 \\
\hline Отрядов & 2 & 2 & 2 & 2 & 2 & 2 & 2 & 2 \\
\hline \multicolumn{9}{|c|}{ КЛАСС ПРЕСМЫКАЮЩИЕСЯ - REPTILIA } \\
\hline Видов & 17 & 10 & 10 & 12 & 11 & 8 & 9 & 19 \\
\hline Семейств & 8 & 4 & 4 & 4 & 4 & 4 & 3 & 8 \\
\hline Отрядов & 3 & 3 & 3 & 3 & 3 & 2 & 2 & 3 \\
\hline \multicolumn{9}{|c|}{ КЛАСС ПТИЦЫ - AVES } \\
\hline Видов & 469 & 378 & 280 & 255 & 267 & 411 & 399 & 513 \\
\hline Семейств & 71 & 63 & 55 & 54 & 57 & 69 & 65 & 72 \\
\hline Отрядов & 22 & 20 & 19 & 19 & 20 & 22 & 21 & 22 \\
\hline \multicolumn{9}{|c|}{ КЛАСС МЛЕКОПИТАЮЩИЕ - МАММАLІА } \\
\hline Видов & 93 & 68 & 69 & 64 & 63 & 80 & 77 & 102 \\
\hline Семейств & 26 & 17 & 18 & 17 & 18 & 27 & 27 & 28 \\
\hline Отрядов & 8 & 6 & 6 & 6 & 6 & 8 & 8 & 8 \\
\hline \multicolumn{9}{|c|}{ ВСЕГО ТЕТРАПОД- ТЕТRAPODA } \\
\hline Видов & 588 & 464 & 368 & 339 & 349 & 507 & 492 & 643 \\
\hline Семейств & 110 & 89 & 82 & 80 & 84 & 105 & 100 & 113 \\
\hline Отрядов & 35 & 31 & 30 & 30 & 31 & 34 & 33 & 35 \\
\hline
\end{tabular}

Наибольшее видовое многообразие наземных позвоночных характерно для югозападного, юго-восточного и северо-восточного секторов Приморского края (соответственно, 588, 507 и 492 вида). Это в первую очередь связано с наличием у них выходов к Японскому морю, в связи с чем, в примыкающих к их берегам акваториях и прилежащих к ним побережьям встречаются отсутствующие в глубине материка прибрежно-морские и сугубо пелагические виды тетрапод.

Несколько меньшее число видов рассматриваемого надкласса (464) выявлено в ханкайском секторе, в то время как в остальных выделах Приморского края их обитает сравнительно мало (см. рисунок), что, вероятно, связано как с реальной видовой бедностью тетрапод на этих участках, так и с недостаточной степенью их изученности. 


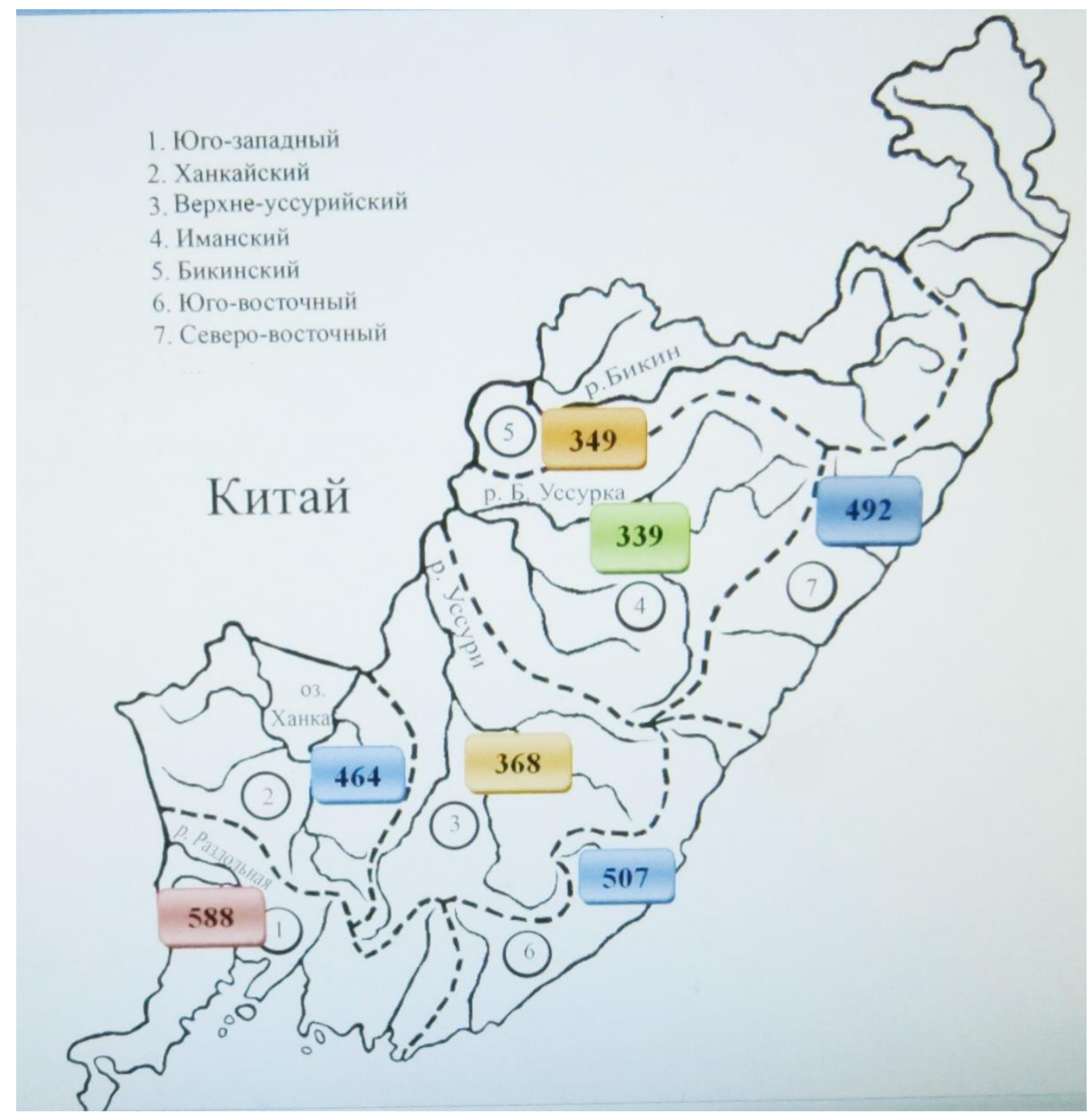

Число видов наземных позвоночных (Tetrapoda) (указано в прямоугольниках), зарегистрированных на различных участках (секторах) территории Приморского края

Следует отметить, что наименее изучен видовой состав морских млекопитающих, обитающих на прилежащей к Приморскому краю акватории Японского моря. К тому же, сведения (в первую очередь картографические), изложенные по этой группе в Красных книгах Российской Федерации (2001) и Приморского края (2005), а также в полевом определителе Ю.Б. Артюхина и В.Н. Бурканова (1999) не всегда достоверны, поскольку порой они не подкреплены никакими конкретными фрактами. По этой причине в составе фрауны Приморья нами не учитывались такие спорные виды как карликовый кашалот (Kogiabreviceps), настоящий клюворыл (Ziphiuscavirostris), серый дельфин (Grampusgriseus), обыкновенная гринда (Globicephalamelas), а также гренландский (Balaenamysticetus) и синий (Balaenopteramusculus) киты.

\section{Литература}

Артюхин Ю.Б., Бурканов В.Н. Морские птицы и млекопитающие Дальнего Востока России: полевой определитель. М.: АСТ, 1999. 215 с.

Бочарников В.Н., Мартыненко А.Б., Глущенко Ю.Н., Горовой П.Г., Нечаев В.А., Ермошин В.В., Недолужко В.А., Горобец К.В., Дудкин Р.В. Биоразнообразие Дальневосточного экорегионального комплекса. Монография. Владивосток, 2004. 292 с.

Глущенко Ю.Н., Бурковский О.А., Вялков А.В., Катин И.О., Коробов Д.В., Прядун Т.А., Федотов А.А., 
Ходаков А.П. Новые наблюдения редких птиц в Приморском крае // Русский орнитологический журнал, 2020. Т. 29. Экспресс-выпуск 1885. С. 579-593.

Глущенко Ю.Н., Нечаев В.А., Глущенко В.П. Птицы Приморского края: фрауна, размещение, проблемы охраны, библиография (справочное издание) // Дальневосточный орнитологический журнал, 2010. № 1. С.3-150.

Глущенко Ю.Н.,Ромашина М.С. Дополнительный материал для изучения строения имногообразия млекопитающих в школьном курсе биологии (на примере видов, населяющих Приморский край) // Животный и растительный мир Дальнего Востока. Вып. 23. Владивосток: ДВФУ, 2015. С. 2849.

Дарман Ю.А., Сторожук В.Б., Седаш Г.А. Hydropotesinermis(Cervidae)-новый вид для фауны России из национального парка «Земля леопарда» (Россия) // NatureConservationResearch. Заповедная наука, 2019. № 4(3). С. 127-129.

Красная книга Приморского края: Животные. Редкие и находящиеся под угрозой исчезновения виды животных. Официальное издание. Владивосток: АВК «Апельсин», 2005. 448 с.

Красная книга Российской Федерации (Животные). М.: АСТ, Астрель, 2001. 862 с.

Кузьмин С.Л., Маслова И.В. Земноводные российского Дальнего Востока. М.: КМК, 2005. 371 с.

Харин В.Е. Биота российских вод Японского моря. Т. 7. Рептилии. Владивосток: Дальнаука, 2008. $170 \mathrm{C}$.

Чугунов Ю.Д. Редкий случай обнаружения морской змеи Pseudolaticaudasemifasciata(Reinwardt) в водах СССР // Зоологический журнал. Т. 59, вып. 3. С. 470-471.

Maslova I.V. The protection of amphibians and reptiles in the Russian Far East // Nature Conservation. 3aповеднаянаука, 2016. 1 (3). С. 26-35.

\title{
Species diversity and territorial distribution of superclass Tetrapoda (Vertebrata, Chordata) of Primorsky Krai
}

\author{
Yu.N. Gluschenko ${ }^{1,2}$, E.I. Tsunov ${ }^{1}$ \\ ${ }^{1}$ Far Eastern Federal University. Branch in the Ussuryisk city (School of pedagogics) \\ ${ }^{2}$ Pacific Geographical Institute FEB RAS (Vladivostok)
}

The publication presents the species diversity and territorial distribution of superclass Tetrapoda (Vertebrata, Chordata), known for the territory of PrimorskyKrai and the adjacent water area of the Sea of Japan.

Keywords: Primorsky Krai, Tetrapoda, species diversity, territorial distribution.

\section{Сведения об авторах:}

Глущенко Юрий Николаевич - кандидат биологических наук, доцент кафедры естественнонаучного образования фрилиала ДВФУ в г. Уссурийске (Школы педагогики). 692500, Приморский край, г. Уссурийск, ул. Некрасова, 35; ведущий научный сотрудник лаборатории экологии и охраны животных Тихоокеанского института географии ДВО РАН. 690041, Приморский край, г. Владивосток, ул. Радио, д.7.E-mail:yu.gluschenko@mail.ru; Цунов Эмиль Игоревич - студент бакалавриата, кафедра естественнонаучного образования фрилиала ДВФУ в г. Уссурийске (Школа педагогики). 692500, Приморский край, г. Уссурийск, ул. Некрасова, 35. E-mail: sleepyonatree@mail.ru. 